\title{
Research on Experiential Teaching Model of English Major in Higher Vocational Education Based on "Four in One” Experience Platform
}

\author{
Liqin Lin \\ Shandong Foreign Languages Vocational College, Rizhao, 276800, China
}

Keywords: “four in one”, Higher Vocational English, experiential type, teaching mode.

\begin{abstract}
In recent years, the reform of Higher Vocational English teaching mode has always been the focus of higher vocational education. This paper summarizes the advantages and disadvantages of several typical Higher Vocational English teaching models, and put forward the "four in one" Experiential English teaching model which integrates classroom teaching, second classroom activities, school simulation training, and practice outside school.
\end{abstract}

\section{Introduction}

Higher vocational education is an important component of China's higher education system. In recent years, the state attaches great importance to the reform of higher vocational education, of which English teaching reform is an important part of higher vocational education reform, and has become a hot topic among scholars. This paper summarizes the existing several typical problems of Higher Vocational English teaching mode on the basis of literature review, put forward the "four in one" experiential English teaching mode. It takes the students as the center, guided by vocational ability training, focuses on experiential teaching to cultivate students' English application ability, so as to create a teaching atmosphere which combines culture, interest, practicability and knowledge, to cultivate applied talents for the society.

\section{Problems in the teaching mode of English reform in Higher Vocational Colleges}

In recent years, the reform of Higher Vocational English teaching carried out in full swing, all the higher vocational colleges are actively trying new teaching models, such as higher vocational English teaching model based on vocational ability, task-based English teaching model and Experiential English teaching model. In the CNKI database, when the "Higher Vocational English teaching reform” is used as a keyword to search, it increased from 1183 documents in 2008 to 1667 in 2016. In this paper, the author chooses three representative Higher Vocational English teaching models and analyzes their advantages and disadvantages.

\subsection{Vocational English Teaching Reform Based on vocational ability training}

Higher vocational English Teaching Reform Based on ability training has become one of the means for many vocational colleges to reform. In CNKI database, when the "ability" and "College English reform" was used as keywords to search documents, articles with preliminary statistics at an average of more than 500 from the year 2012 to 2017, and most of them carries out the research on the reform of teaching methods, teaching evaluation and other aspects. For example, Zhang Mingyong carried out a questionnaire survey on 210 sophomores of different majors in Wuhan Polytechnic and 40 school enterprise cooperation units or graduates. On the one hand, it investigates the students' English learning and the influence of Higher Vocational English teachers' teaching ideas and methods on students' vocational ability. The result shows that the English teaching model of vocational ability training in schools has not achieved satisfactory results, and the practical application ability of students listening, speaking, reading and writing is low. The reason is that 
teachers lack the correct understanding of the English teaching concept of vocational ability training and pertinence and effectiveness in teaching content and methods, public English, and students' interest in English learning is not high. These factors have led to that the English teaching model of vocational ability has not given full play to the guiding function of market demand, has not play a positive role in promoting students' professional practice ability ${ }^{[1]}$. In theory, the teaching mode is consistent with the current higher vocational English teaching objectives, highlights the occupation ability, but the attention rate of content of teaching, students' basic English ability, classroom atmosphere and other aspects is relatively weak, resulting in the teaching mode cannot arouse students the awareness of autonomous learning the actual teaching, unable to get rid of the traditional teaching methods that bases on instruction.

\subsection{The reform of Higher Vocational English teaching mode by means of Internet information technology and platform}

The updating and development of network technology provides a personalized network selflearning platform for Higher Vocational education. At present, many higher vocational colleges actively use advanced network platform to reform higher vocational English teaching mode, and the higher vocational English teaching model based on network platform in Jiaxing Vocational and Technical College is one of them. This teaching model is based on Swiss psychologist Piaget's learning theory and network information technology. Through questionnaire survey data, students are more inclined to network platform teaching model. By changing students' learning concepts and correcting their learning motivation, the teaching model can improve students' information literacy and autonomous learning strategies, and strengthen their ability of autonomous learning, hope to achieve the optimization of English teaching mode based on network platform ${ }^{[2]}$. It should be pointed out that operational capability of language must be substantially improved in language practice. And although this teaching mode provides students with personalized and diversified classroom content, it does not give due attention to the creation of classroom situations, especially to extracurricular practice, which is obviously not conducive to the improvement of students' operational capability of language and professional ability.

\subsection{Experiential higher vocational English Teaching Reform}

Vocational colleges. Dai Rixin and Peng Xuanhong focuses on the theory of experiential learning based on Kolb in "The concept and implementation of experiential teaching model in Higher Vocational English", and on the basis of this, combine "student centered", "Based on occupational activity orientation" and "Characterized by experiential activity teaching" as an integrated approach to build experiential teaching model. The model is divided into specific experience, reflection, observation, abstract and active application, and stimulates students' interest by creating situations. In teaching practice, teachers and students should make full preparation of the material, determine the subject, students are trained to listen, speak, read and write in four steps in specific situations around the professional topics that students are interested in with the help of multimedia technology ${ }^{[3]}$. Experiencing English teaching has obvious advantages, but it requires students to complete the preparation according to the teacher's requirements, at the same time, teachers should carefully study and standardize the teaching process of experiential teaching so as to give full play to their advantages, otherwise it will become a mere formality. However, most of the experiential teaching models implemented in higher vocational colleges are limited to the creation of school classroom situations, and there is still insufficient attention to outside school practice.

To sum up, the above typical English teaching model has obvious advantages and disadvantages. Based on the above analysis, the author puts forward a "four in one" experiential English teaching model which integrates classroom teaching, students' autonomous learning, classroom training and extracurricular practice. This model absorbs the advantages of the above teaching models, considers students as center, the occupation ability as the guidance, the language practice platform inside and outside the classroom is fused together, aiming at training students' operational capability of language and professional ability. 


\section{The "four in one" experiential teaching model}

\subsection{Connotation of "four in one" experiential teaching model}

It emphasizes the practical teaching, takes the employment as the guidance to train the front-line technology applied talented person, summarize the advantages and disadvantages of various teaching models, constructs a "four in one" experiential English teaching model which integrates classroom teaching, second classroom activities, school simulation training, and extracurricular practice (as shown below).

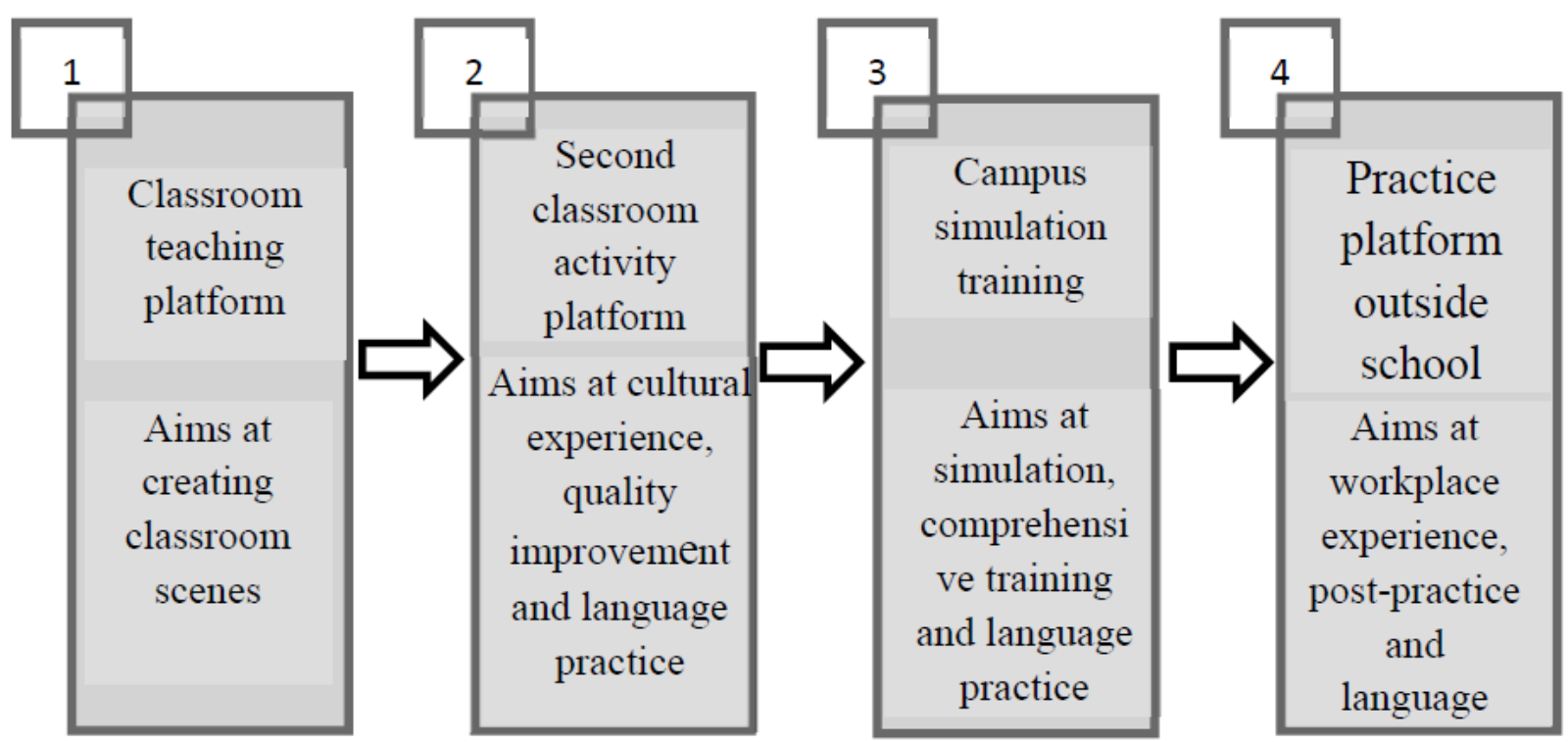

Figure 1. "Four in one" teaching model of English experiential teaching

The "four in one" experience platform designed in this paper is based on the characteristics of the theory and practice of Higher Vocational English course. The four platforms are connected and deepened step by step, aiming at strengthening the mastery of students' theoretical knowledge and improving their language competence and practical ability.

\section{The implementation of "four in one" English experience teaching mode}

From the theory or practice, the "four in one" experiential teaching model has a strong advantage. The implementation of the "four in one" experiential teaching mode requires the following conditions:

First of all: higher quality teachers. On the one hand, teachers need to have "Dual Teacher" literacy, both high level of theoretical knowledge and rich practical experience. On the other hand, we should actively develop the professional quality of teachers, encourage English teachers to practice in enterprises, and be familiar with the requirements of specific positions for English majors. In addition, the school enterprise cooperation units should be invited to give professional lectures for students regularly.

Second: the corresponding teaching materials and the teaching content with the times. Teaching material is one of the bases of carrying out the "four in one" teaching model. Higher vocational colleges should break through the content of traditional teaching materials according to the characteristics of schools and different majors, take students as the core and cultivate vocational ability as the main line, and the necessary teaching materials are compiled. Teaching content is the focus of the "four in one" teaching mode. We should integrate the teaching content and design the teaching theme according to the needs of the training of students' Vocational ability. Taking business English major as an example, the teaching content should be integrated into the classroom according to the requirements of economic development, and the practicability and operability of the teaching content will be enhanced. 
Third: teaching methods that students are the main body. The teaching method is the key to carry out the "four in one" experiential teaching mode. The "four in one" experiential teaching model aims at cultivating students' comprehensive abilities in analysis, negotiation, interpersonal communication and intercultural communication. This requires that in the teaching practice, we should abandon the teaching methods which are mainly explained by teachers, and integrate more situational teaching, task teaching and project teaching methods.

Fourth: close training inside and outside the school. English listening, speaking, reading, writing, translation and other ability can have substantive improvement, only in the concrete practice of training. Training inside and outside the school is undoubtedly one of the effective methods. The campus simulation training can provide comprehensive simulation training for English majors, and experience the workflow of specific positions, and deepen the study of theoretical knowledge. School enterprise cooperation units can provide students with real job practice, and can provide practical guidance for students. They have opened channels for close experience, real work flow and improving interpersonal communication ability. It is worth pointing out that school simulation training (before) and off campus practice (after) is inseparable.

Fifth: strong self-learning ability. Classroom teaching, second classroom activities, school training and off campus practice require students to study actively under the guidance of teachers. Only in this way can we improve the teaching effect in and out of class.

Therefore, when higher vocational colleges carry out the "four in one" experiential teaching mode, it must strengthen the cultivation of students; learning initiative, emphasize the cultivation of autonomous learning ability, help students analyze the situation, advantages and disadvantages of their own learning, and timely improve for deficiencies.

\section{Conclusion}

In conclusion, the "four-in-one" experiential teaching mode has some obvious superiority, and it is an innovation to adopt this mode in higher vocational English teaching. In order to train more excellent talents to meet the needs of society, higher vocational colleges should study carefully their own geographical and subject advantages, and then develop the teaching content, teaching methods and evaluation system which are suitable for the students.

\section{Acknowledgements}

This paper is the staged achievement of the research project titled "Research on the Application of Experiential Teaching Method in Higher Vocational English Teaching” supported by Shangdong Province Educational Science “ $12^{\text {th }}$ Five-Year" Pan Project in 2015 (Higher Education Foreign Language Teaching Subject) (No.CGW15014).

\section{References}

[1] Liu C F, Jin-Chao M U. Research on Experiential Teaching Practice to Biological Food Specialty in Higher Vocational Colleges Based on Production,Education\& Research Platform [J]. Journal of Anhui Agricultural Sciences, 2016.

[2] Han W U. Exploration and Practice of English Teaching Model based on the Cultivation of Occupational Ability in Higher Vocational Colleges [J]. Journal of Guangdong Technical College of Water Resources \& Electric Engineering, 2010.

[3] Xu L. A Study on qExperientialq English Teaching Mode of Higher Vocational Colleges [C] International Conference on Education, Management and Computing Technology. 2015. 